\title{
Assessment of Potability of Minewater Pumped Out from Jharia Coalfield, India: An Integrated Approach Using Integrated Water Quality Index, Heavy Metal Pollution Index and Multivariate Statistics
}

\section{Pritam Mazinder Baruah}

IIT (ISM): Indian Institute of Technology https://orcid.org/0000-0001-5188-2988

Gurdeep Singh ( $\nabla$ gurdeepsingh.iit.ism@gmail.com )

IIT (ISM): Indian Institute of Technology

\section{Research Article}

Keywords: Minewater potability, Integrated Water Quality Index, Minewater quality, Jharia Coalfield, Heavy Metal Pollution Index, Multivariate Statistics

Posted Date: September 21st, 2021

DOI: https://doi.org/10.21203/rs.3.rs-809314/v1

License: (c) (i) This work is licensed under a Creative Commons Attribution 4.0 International License.

Read Full License 


\section{Abstract}

The dense and industrialized populace in the mining areas of Jharia Coalfield (JCF) is plagued by a severe shortage of water supply. The unutilized pumped out coal minewater discharges may be utilized to cater to the increasing water demand of the region but it runs the risk of getting contaminated from domestic and industrial effluents. The current study aimed to assess the suitableness of augmenting underground minewater for potable purposes. Minewater samples collected from 15 locations (minewater treatment plants) across JCF for the hydrological year 2019-2020 were analysed to gain an insight on the physico-chemical characteristics of the minewater using an integrated approach of standard hydrochemical methods, Integrated Water Quality Index (IWQI), Heavy metal Pollution Index $(\mathrm{HPI})$ and Multivariate Statistical Analysis. The integrated approach gives a holistic assessment of the minewater quality, overcoming the limitations of traditional water quality indices, to give a more accurate assessment. The analysis of minewater in the region identified $\mathrm{Ca}-\mathrm{Mg}-\mathrm{HCO}_{3}$ and $\mathrm{Ca}-\mathrm{Mg}-\mathrm{Cl}-\mathrm{SO}_{4}$ as the two major water types. Principal Component Analysis (PCA) and Hierarchical Cluster Analysis (HCA) of the minewater revealed the influence of lithogenic and anthropogenic processes in modulating the water chemistry of the region. This study could facilitate effective water quality management practices while also laying the foundation for augmenting minewater for potable purposes to meet increasing demands.

\section{Introduction}

About one-sixth of the global population lack access to water of potable quality (WHO 2012), despite global advancements in technology and economy. Minewater discharged during mining operations is a valuable water resource, but it runs the risk of getting contaminated from domestic and industrial effluents. Drinking contaminated water effects human health adversely, stymying the growth and development of the region (Milovanovic 2007). The monitoring and accurate assessment of minewater quality to determine the type of treatment required (if any) before its utilization for potable purposes, thus gains importance. The Bureau of Indian Standards (BIS) define permissible limit as the maximum admissible concentration and acceptable limit as the minimum required concentration of ionic content in water. For maintenance of mineral homeostasis, the concentration of ionic content in the water needs to be within range of both the threshold limits. Studies on mineral deficiency have revealed its adverse effects on the human health (Rylander 2008; Shu 2015). The overall water quality of a region is summarized by means of water quality indices which assess spatio-temporal variations in water quality, enabling information on the water quality to be relayed to concerned stakeholders. Various indices differ from one another in the way the sub-index is chosen (Ponsadailakshmi et al. 2018). These sub-indices contain information on individual parameters affecting water quality. The suitableness of water quality for potability could be done using water quality indexing. While traditional water quality indices (WQI) consider the values of physicochemical parameters below the acceptable limits to be good without accounting for the ion-deficiency in the water, giving an erroneous assessment of water quality, IWQI uses 
both- acceptable/desirable limits and permissible limits in its assessment of water quality from the aspect of ion concentration in the minewater.

In this paper, we shall seek to give an insight on the potability of minewater pumped out from Jharia Coalfield by assessment of its quality using an integrated approach which constitutes application of the Integrated Water Quality Index (IWQI) Model, Heavy Metal Pollution Index (HPI) Model and Multivariate Statistics. This holistic approach evaluates water quality from the aspect of concentration of major ions, physical attributes like $\mathrm{pH}, \mathrm{EC}$, TDS and trace/heavy metals, the results of which are corroborated by multivariate statistical analysis. Limitations of commonly used WQI Models are overcome by use of this approach, presenting a holistically accurate assessment of minewater quality of Jharia Coalfield.

\section{Materials And Methods}

\subsection{Description of study area}

Jharia Coalfield is a sickle-shaped terrain that spreads across a $450 \mathrm{~km}^{2}$ area between $23^{\circ} 37^{\prime} \mathrm{N}-23^{\circ} 52^{\prime}$ $\mathrm{N}$ latitudes and $86^{\circ} 09^{\prime} \mathrm{E}-86^{\circ} 30^{\prime} \mathrm{E}$ longitudes with an altitude averaging 220 metres above mean sea level, situated in Dhanbad district, in the Indian state of Jharkhand. It is located at the centre of Damodar valley, forming a part of the Gondwana Coalfield, having undergone a vast array of anthropologically induced changes over the last century that has affected the environment around it (Singh et al. 2012). The hydraulic gradient changes with mine development- both at the surface and underground, below the piezometric level, affecting the flow regimes of surfacewater and groundwater (Sarkar et al. 2007).

The study sites selected for collecting minewater samples comprised of 15 operational minewater treatment plants (MWTPs) spread across Jharia Coalfield (Fig. 1). The MWTPs are in the mining areas of Mudidih, West Mudidih, Ramkanali, Kharkharee, Sinidih, Muraidih, Shatabdi, Bastacolla, Victoria, Bera, Kuya, South Tisra, Khas Kusunda, Pootkee-Balihari (P.B.) Area, which are owned by Bharat Coking Coal Limited (BCCL).

\subsection{Sampling and analysis}

Two sampling campaigns were carried out in the pre-monsoon and post-monsoon seasons of MarchApril and October-November, respectively for the hydrological year 2019-2020. Ninety underground coal minewater samples ( 3 composite samples from each of the 15 minewater treatment plants operating in JCF, Jharkhand) were collected from the storage tank outlets of the minewater treatment facilities in highdensity polyethylene bottles (pre-washed) of 1 litre capacity for the year 2019-2020. In each site, three field duplicates were collected and well mixed in situ subsequently. A total of 14 physicochemical parameters and 9 trace/heavy metals (Iron, Manganese, Zinc, Nickel, Lead, Copper, Chromium, Arsenic and Cadmium) determining water quality of the region were analysed. Type-I $(18.2 \mathrm{M} \Omega \mathrm{cm})$ Milli-Q water was used to prepare all the solutions. $\mathrm{EC}, \mathrm{pH}$, and TDS values were gauged on-site using Multiparameter $\mathrm{pH}$ Tester 35 Ecotech instrument. Total alkalinity (titration with $0.02 \mathrm{~N} \mathrm{H}_{2} \mathrm{SO}_{4}$ using phenolphthalein and methyl orange indicator), total hardness (titration with EDTA), sulphate (turbidimetric method), nitrate 
(spectrophotometric method), chloride (argentometric method) and fluoride (SPADNS method) were analysed using UV-visible spectrophotometer (UV-1800 Shimadzu), as per the methods prescribed in APHA 2017. Duplicate blanks and a laboratory water standard were analysed for quality control. EDTA titration method was used to analyse calcium while magnesium was determined by multiplying the magnesium hardness by a factor of 0.2431 . Potassium and sodium were determined by the flame photometer (ESICO, M-1385). The trace/heavy metal concentration in the minewater was determined after digestion of the samples with $1 \mathrm{~N} \mathrm{HNO}_{3}$ prior to its analysis, using GBC Avanta PM Atomic Absorption Spectrophotometer in flame mode at the recommended wavelengths. Bacteriological analysis such as coliform count was not carried out for this study as previous qualitative studies on pumped-out underground minewater of Jharia Coalfield consistently showed no such contamination. The spatial distribution of the integrated water quality index was drawn using IDW technique in ArcGIS 10.2.2 software.

\subsection{Quality control and quality assurance}

The quality control and quality assurance were checked by corroborating analytical methods based on appropriate standards (calibration, blank reagents, detection limit and accuracy) during all measurements. The calculation of correlation coefficient $\left(R^{2}=0.99\right)$ of standard curves of known concentrations of anions and cations confirmed the accuracy of results. The accuracy of the chemical analysis of the minewater samples were determined by calculating the lonic Balance Error (IBE), as shown in the equation:

$$
B=\frac{C-A}{C+A} \times 100
$$

Where, $A$ and $C$ are the concentrations of total anions and cations in milliequivalent per litre $(\mathrm{meq} / \mathrm{L})$ and $B$ is the percentage of ionic balance error. To increase the accuracy of the analysis, values of $B$ upto $10 \%$ were considered (Yadav et. al, 2020).

\subsection{Compilation of data and statistical methodology}

Data compiled during the study followed the standard methods prescribed by APHA (2017). This data was processed using IWQI, HPI and Multivariate Statistical Analysis.

\subsubsection{Calculation of IWQI}

IWQI was applied to the coal minewater samples to evaluate the minewater quality and its suitableness for consumption. Studies have revealed that the optimal protective or beneficial effects of drinking water on human health occur at acceptable concentrations (Kozisek 2005). Therefore, acceptable limits (AL) and permissible limits $(\mathrm{PL})$ values of the water quality parameters are assigned by the BIS based on the hazard it poses to human health (Table 1). The values between the two threshold limits fall under the range which can also be represented as the difference in deficit (15\%) of the range of the specific water 
quality parameter from its permissible limit (PL) to give Modified Permissible Limit (MPL) given in Table 1. The percentage (\%) deficit can be changed as per the situation and is used to buy time to alleviate the existing contamination levels, preventing contamination from crossing the threshold level which otherwise could adversely affect the environment around it (S. Mukate et al. 2019). The values that fall within the AL and MPL are considered ideal for consumption. When the value of $x^{\text {th }}$ water quality parameter $\left(Q_{X}\right)$ is higher than $\mathrm{AL}$ but lower than MPL i.e. $\mathrm{AL} \leq Q_{X} \geq \mathrm{MPL}$, the value of the sub index $\left(\mathrm{SI}_{1}\right)$ is taken as zero. When the value of $x^{\text {th }}$ water quality parameter is lesser than the acceptable limit i.e. $Q_{x} \leq$ $\mathrm{AL}$, then $\mathrm{SI}_{2}=\frac{\left(A L-Q_{X}\right)}{A L}$

When the water quality parameter has a higher value than the MPL i.e. $Q_{x} \geq \mathrm{MPL}$,

then $S I_{3}=\frac{\left(Q_{x}-M P L\right)}{M P L}$

To compute the sub-indices, division of the difference in the specific water quality parameter $\left(Q_{x}\right)$ with its acceptable limit (AL) or Modified Permissible Limit (MPL) is done by its respective AL or MPL. This is done to obtain a homogenized value for identification of increased or decreased concentration of a specific parameter with respect to its AL or MPL. These computed values are added to get the Integrated Water Quality Index (IWQI).

$$
I W Q I_{x}=\sum_{y=1}^{n} S I_{x y}
$$

where $S I_{x y}=$ value of sub-index of $x^{\text {th }}$ sample and $y^{\text {th }}$ water quality parameter.

The above equation is used in the calculation of IWQI. The quality of the analysed minewater samples were classified as- excellent $(<1)$, good $(1-2)$, poor $(2-3)$, very poor $(3-5)$ and unsuitable $(>5)$ depending upon their IWQI value (Table 2) which depends upon the ionic $\left(\mathrm{Mg}^{2+}, \mathrm{Ca}^{2+}, \mathrm{K}^{+}, \mathrm{Na}^{+}, \mathrm{Cl}^{-}, \mathrm{F}^{-}, \mathrm{SO}_{4}{ }^{2-}, \mathrm{NO}_{3}{ }^{-}\right)$ concentration along with $\mathrm{pH}, \mathrm{TDS}$, total hardness and total alkalinity present in the samples.

Table 1 Water quality standards (BIS 2012) with modified permissible limits for drinking 


\begin{tabular}{|c|c|c|c|c|}
\hline Parameters & $\begin{array}{l}\text { Acceptable Limit } \\
\text { (AL) }\end{array}$ & $\begin{array}{l}\text { Permissible Limit } \\
(\mathrm{PL})\end{array}$ & Range & $\begin{array}{l}\text { Modified Permissible } \\
\text { Limit } \\
\text { (MPL= PL- } 15 \% \text { of } \\
\text { Range) }\end{array}$ \\
\hline $\mathrm{pH}$ & 6.5 & 8.5 & 2 & 8.2 \\
\hline Total Hardness (TH) & 200 & 600 & 400 & 540 \\
\hline Total Alkalinity (TA) & 200 & 600 & 400 & 540 \\
\hline $\begin{array}{l}\text { Total Dissolved Solids } \\
\text { (TDS) }\end{array}$ & 500 & 2000 & 1500 & 1775 \\
\hline Calcium $\left(\right.$ as $\left.\mathrm{Ca}^{++}\right)$ & 75 & 200 & 125 & 181.25 \\
\hline Magnesium $\left(\right.$ as $\mathrm{Mg}^{++}$) & 30 & 100 & 70 & 89.5 \\
\hline Sodium (as $\mathrm{Na}^{+}$) & - & - & - & - \\
\hline Potassium (as K ${ }^{+}$) & - & - & - & - \\
\hline Chloride (as $\mathrm{Cl}^{-}$) & 250 & 1000 & 750 & 887.5 \\
\hline Fluoride (as $\mathrm{F}^{-}$) & 1.0 & 1.5 & 0.5 & 1.425 \\
\hline Bicarbonate $\left(\mathrm{HCO}_{3}^{-}\right)$ & - & - & - & - \\
\hline Sulphate $\left(\mathrm{SO}_{4}{ }^{2-}\right)$ & 200 & 400 & 200 & 370 \\
\hline Nitrate $\left(\mathrm{NO}_{3}^{-}\right)$ & 45 & 45 & 0 & 45 \\
\hline
\end{tabular}

${ }^{\dagger}$ No guideline values have been established for some of the parameters as its concentration levels do not concern health. All the parameters are in $\mathrm{mg} \mathrm{L}^{-1}$, barring $\mathrm{pH}$.

Table 2 Categorization of quality of minewater based on IWQI (S. Mukate et al., 2019)

\begin{tabular}{|lll|}
\hline IWQI values & Category & Assessment of water quality \\
\hline$<1$ & Excellent & Ideal for potable purposes \\
\hline $1-2$ & Good & Fit for potability and domestic purposes \\
\hline $2-3$ & Poor & Only for domestic purposes \\
\hline $3-5$ & Very Poor & Need attention prior to its usage \\
\hline$>5$ & Unsuitable & Harmful to human health \\
\hline
\end{tabular}


The trace/heavy metal contamination affecting minewater quality were evaluated by computing the analysed samples with HPI, an indexing model which incorporates weighted arithmetic quality in assigning weights $\left(W_{x}\right)$ ranging from 0 to 1 to individual metals (Singh and Kamal 2017). The value for critical pollution index is set at 100 for drinking water (Bhardwaj et al. 2017). The standard for the analysed minewater quality parameter is designated as $S_{X}$ which is in inverse proportion to the unit weightage $\left(W_{x}\right)$ of the respective minewater quality parameter.

The formula proposed by Mohan et al. (1996) was utilized in calculation of HPI

$$
H P I=\frac{\sum_{x=1}^{n} W_{x} Q_{x}}{\sum_{x=1}^{n} W_{x}}
$$

where $W_{x}$ denotes unit weightage of $x^{\text {th }}$ minewater quality parameter, sub-index of the $x^{\text {th }}$ parameter is denoted by $Q_{x}$ and $\mathrm{n}$ is the number of minewater quality parameters analysed. $W_{x}$ is computed by applying the formula:

$$
W_{x}=\frac{p}{S_{x}}
$$

where the permissible limit (BIS 2012) of $x^{\text {th }}$ minewater quality parameter is denoted by $S_{x}$ and $p$ is assigned to be the proportionality constant. $Q_{x}$ denotes sub-index of $x^{\text {th }}$ minewater quality parameter and was calculated using the formula:

$$
Q_{x}=100 \times \frac{M_{x}}{S_{x}}
$$

where $S_{X}$ is the permissible limit (BIS 2012) for the $x^{\text {th }}$ parameter and $M_{X}$ which is expressed in $\mu \mathrm{g} \mathrm{L}^{-1}$ denotes monitored value of $x^{\text {th }}$ minewater quality parameter. In this study, HPI values were grouped into three categories which have been demarcated as high $(>30)$, medium $(15-30)$ and low $(<15)$ depending upon trace/heavy metal concentration in the analysed minewater (Giri and Singh 2014; Panigrahy et al. 2015; Tiwari et al. 2015).

\subsubsection{Multivariate Statistics and Geostatistical modelling}

PCA and HCA were used in identifying the minewater contamination source and the similarities among the sampling locations, respectively. PCA and HCA of the analysed data was done using XLSTAT 2019.1 software to reduce the large dataset for interpreting patterns within the data. The original dataset was reduced after alteration into newer group of variables known as principal components, which were obtained from linear combinations of variables of the original data set and categorized in a manner that the first principal components are accountable for variations in the original data set (Ogwueleka 2015; Kamtchueng et al. 2016). 
The minewater quality of the study area was represented spatially using Inverse Distance Weightage (IDW) method to interpolate IWQI and HPI data in Arc GIS 10.2.2. This method weighs the sampling points during interpolation in a manner that the impact of one point over the other increases with decrease in relative distance from the unknown point created for the study.

\section{Results And Discussion}

\subsection{Physico-chemical characteristics}

The analysis of physicochemical parameters of the pumped-out coal minewater samples from 15 minewater treatment facilities (sampling sites) operating across Jharia Coalfield during the hydrological year 2019-2020 revealed variations in $\mathrm{pH}$ ranging from 6.5 to 8.3 with an arithmetic mean of 7.7, suggesting the nature of the coal minewater to be between mildly acidic and alkaline. The electrical conductivity (EC) of the coal minewater samples ranged between 568 and 1,389 $\mu \mathrm{S} \mathrm{cm}^{-1}$ (mean-1,016 $\mu \mathrm{S} \mathrm{cm}^{-1}$ ), which could be attributed to the heterogeneity of the underlying aquifers, which are compartmental hydrological processes, not contiguous with the overall groundwater circulation (Rakotondrabe et al. 2018). The TDS concentration in the coal minewater showed variation between 341 and $953 \mathrm{mg} \mathrm{L}^{-1}$ (mean- $674 \mathrm{mg} \mathrm{L}^{-1}$ ). This fluctuation could be a result of existing mining conditions in the region, variations in geological formations and underlying hydrosystems (Singh et al. 2012). A descriptive statistics of physicochemical characteristics of the minewater quality parameters with its respective acceptable limit (AL) and permissible limit $(P L)$ is represented in Table 3. Previous qualitative studies on pumped-out underground minewater of Jharia Coalfield consistently showed no contamination of Coliform bacteria as the samples were sourced from underground coalmines which were directly pumped out and stored in reservoirs. As a result, in this study, microbiological indicators such as coliform count was not used in calculating IWQI- to characterize the quality of pumped-out underground coal minewater. 
Table 3

Statistical summary of physico-chemical characteristics of the sampled minewater

\begin{tabular}{|c|c|c|c|c|c|c|c|c|}
\hline \multirow[t]{2}{*}{ Parameters } & \multirow[t]{2}{*}{ Unit } & \multicolumn{4}{|c|}{ Coal minewater samples } & \multicolumn{2}{|c|}{ BIS (2012) } & \multirow{2}{*}{$\begin{array}{l}\text { WHO } \\
(2011)\end{array}$} \\
\hline & & Min & Max & Mean & SD & $\mathrm{AL}$ & PL & \\
\hline \multicolumn{9}{|l|}{ Major ions } \\
\hline $\mathrm{pH}$ & - & 6.5 & 8.3 & 7.7 & 0.5 & 6.5 & 8.5 & $6.5-8.5$ \\
\hline EC & $\mu S \mathrm{~cm}^{-1}$ & 568 & 1389 & 1016 & 212.4 & - & - & 1500 \\
\hline TDS & $\mathrm{mg} \mathrm{L}^{-1}$ & 341 & 953 & 674 & 152.9 & 500 & 2000 & $600-1000$ \\
\hline TH & $\mathrm{mg} \mathrm{L}^{-1}$ & 149 & 719 & 444 & 151.8 & 200 & 600 & - \\
\hline TA & $\mathrm{mg} \mathrm{L}^{-1}$ & 23 & 403 & 179 & 107.3 & 200 & 600 & - \\
\hline $\mathrm{Ca}^{++}$ & $\mathrm{mg} \mathrm{L}^{-1}$ & 34 & 131 & 82 & 29.59 & 75 & 200 & 75 \\
\hline $\mathrm{Mg}^{++}$ & $\mathrm{mg} \mathrm{L}^{-1}$ & 16 & 116 & 58 & 28.00 & 30 & 100 & 125 \\
\hline $\mathrm{Na}^{+}$ & $\mathrm{mg} \mathrm{L}^{-1}$ & 9.7 & 133 & 34.5 & 26.13 & - & - & 200 \\
\hline $\mathrm{K}^{+}$ & $\mathrm{mg} \mathrm{L}^{-1}$ & 1.2 & 12.4 & 5.0 & 2.88 & - & - & 12 \\
\hline $\mathrm{TZ}^{+}$ & meq $L^{-1}$ & 4.43 & 13.35 & 9.95 & 2.29 & - & - & - \\
\hline $\mathrm{Cl}^{-}$ & $\mathrm{mg} \mathrm{L}^{-1}$ & 9.0 & 151.4 & 42.3 & 30.57 & 250 & 1000 & 250 \\
\hline $\mathrm{F}^{-}$ & $\mathrm{mg} \mathrm{L}^{-1}$ & 0.09 & 2.58 & 0.67 & 0.49 & 1 & 1.5 & 1.5 \\
\hline $\mathrm{HCO}_{3}^{-}$ & $\mathrm{mg} \mathrm{L}^{-1}$ & 29 & 492 & 220 & 129.3 & - & - & $125-130$ \\
\hline $\mathrm{SO}_{4}{ }^{2-}$ & $\mathrm{mg} \mathrm{L}^{-1}$ & 48 & 629 & 293 & 160.9 & 200 & 400 & 250 \\
\hline $\mathrm{NO}_{3}^{-}$ & $\mathrm{mg} \mathrm{L}^{-1}$ & 0.25 & 34.59 & 7.40 & 9.15 & 45 & 45 & 50 \\
\hline $\mathrm{TZ}^{-}$ & meq $L^{-1}$ & 4.76 & 14.10 & 10.38 & 2.28 & - & - & - \\
\hline \multicolumn{9}{|c|}{ Trace/heavy metals } \\
\hline $\mathrm{Fe}$ & $\mu \mathrm{g} \mathrm{L}^{-1}$ & 175 & 626 & 374 & 122.4 & 300 & 300 & 300 \\
\hline $\mathrm{Mn}$ & $\mu g \mathrm{~L}^{-1}$ & 3.1 & 697.4 & 100.5 & 187.2 & 100 & 300 & $100-400$ \\
\hline $\mathrm{Cd}$ & $\mu \mathrm{g} \mathrm{L}^{-1}$ & 0.01 & 0.37 & 0.10 & 0.08 & 3 & 3 & 3 \\
\hline
\end{tabular}

${ }^{+}$No guideline values have been established for some of the parameters as its concentration levels do not concern health. SD = Standard Deviation. 


\begin{tabular}{|c|c|c|c|c|c|c|c|c|}
\hline \multirow[t]{2}{*}{ Parameters } & \multirow[t]{2}{*}{ Unit } & \multicolumn{4}{|c|}{ Coal minewater samples } & \multicolumn{2}{|c|}{ BIS (2012) } & \multirow{2}{*}{$\begin{array}{l}\text { WHO } \\
\text { (2011) }\end{array}$} \\
\hline & & Min & Max & Mean & SD & $\mathrm{AL}$ & PL & \\
\hline $\mathrm{Cu}$ & $\mu \mathrm{g} \mathrm{L}^{-1}$ & 3.7 & 60.9 & 14.3 & 12.80 & 50 & 1500 & 2000 \\
\hline $\mathrm{Ni}$ & $\mu g \mathrm{~L}^{-1}$ & 5.7 & 32.7 & 14.7 & 7.31 & 20 & 20 & 70 \\
\hline $\mathrm{Pb}$ & $\mu g L^{-1}$ & 7.2 & 24.8 & 11.9 & 4.64 & 10 & 10 & 10 \\
\hline Zn & $\mu \mathrm{g} \mathrm{L}^{-1}$ & 13 & 109 & 46 & 28.61 & 5000 & 15000 & 3000 \\
\hline $\mathrm{Cr}$ & $\mu \mathrm{g} \mathrm{L}^{-1}$ & 2.9 & 24.0 & 6.9 & 5.23 & 50 & 50 & 50 \\
\hline As & $\mu g \mathrm{~L}^{-1}$ & 0.2 & 25.2 & 5.4 & 7.40 & 10 & 50 & 10 \\
\hline
\end{tabular}

\subsubsection{Characteristics of major ions}

The cationic concentration of major ions in the coal minewater of JCF in order of their relative abundance was: Calcium > Magnesium > Sodium > Potassium, while the anionic concentrations were in the order: Sulphate $>$ Bicarbonate $>$ Chloride $>$ Nitrate $>$ Fluoride. The value for the total cationic charge $\mathrm{TZ}^{+}$ranged between 4.43 and 13.35 meq $L^{-1}$, (mean- 9.95 meq $^{-1}$ ). The total anionic charge $\left(\mathrm{TZ}^{-}\right)$ranged between $4.76 \mathrm{meq} \mathrm{L}^{-1}$ and 14.10 meq $\mathrm{L}^{-1}$, having an arithmetic mean of $10.38 \mathrm{meq} \mathrm{L}^{-1}$. Charge balance error upto $\mathrm{N} \pm 5 \%$ was considered acceptable for all the minewater samples $(N) .37 \%$ of the samples showed a charge balance error exceeding $5 \%$, exhibiting a deficit in total cations. This could be due to an anionic excess because of accumulation of contaminated load due to mining operations near the area of study. Analysis revealed calcium, magnesium (major cations), bicarbonate and sulphate (major anions) to be the dominant ions responsible for the TDS in the coal minewater of JCF, contributing $30.38,36.93,10.50$ and $7.70 \%$ of the total TDS, respectively. Chloride (6.23\%) and sodium (5.31\%) were the secondary contributors, while nitrate, potassium and fluoride collectively accounted for just $1.95 \%$ of the TDS. Bicarbonates with concentrations varying between $29 \mathrm{mg} \mathrm{L}^{-1}$ and $492 \mathrm{mg} \mathrm{L}^{-1}$, (mean- $220 \mathrm{mg} \mathrm{L}^{-1}$ ) were most dominant in the minewater of Muraidih, Shatabdi and Pootkee-Balihari Area of JCF. This could be the result of sequestration of $\mathrm{CO}_{2}$ from the soil zone, reaction of silicates in the underlying soil layer with carbonic acid and carbonate dissolution. The decaying of organic matter in the subsurface of the soil zone along with root respiration results in a rise in $\mathrm{CO}_{2}$ pressure in the subsurface environment, which on contact with percolated rainwater form bicarbonates (Singh et al. 2012). The variation in sulphate concentration, ranged between $48 \mathrm{mg} \mathrm{L}^{-1}$ and $629 \mathrm{mg} \mathrm{L}^{-1}$ (mean- $294 \mathrm{mg} \mathrm{L}^{-1}$ ) showed higher concentration in the minewater of Jamunia, Mudidih, West Mudidh, Ramkanali, Victoria, Bera and Kuya. The oxidative weathering of pyrites $\left(\mathrm{FeS}_{2}\right)$, anhydrite $\left(\mathrm{CaSO}_{4}\right)$ and gypsum $\left(\mathrm{CaSO}_{4} \cdot 2 \mathrm{H}_{2} \mathrm{O}\right)$ in the underlying rocks of the region could be a major contributing factor in the higher concentrations of $\mathrm{SO}_{4}{ }^{2-}$. 
The chloride concentration varied between $9.0 \mathrm{mg} \mathrm{L}^{-1}$ and $151.4 \mathrm{mg} \mathrm{L}^{-1}$ (mean- $43.3 \mathrm{mg} \mathrm{L}^{-1}$ ). The spatial distribution of chloride concentration was below the maximum acceptable limit of $250 \mathrm{mg} \mathrm{L}^{-1}$ in all the sampling locations. The fluoride concentration, which varied from $0.12 \mathrm{mg} \mathrm{L}^{-1}$ to $2.58 \mathrm{mg} \mathrm{L}^{-1}$ (mean- $0.67 \mathrm{mg} \mathrm{L}^{-1}$ ) contributed to less than $1 \%$ of total anionic balance. Calcium concentration in the coal minewater of JCF varied between $34 \mathrm{mg} \mathrm{L}^{-1}$ and $131 \mathrm{mg} \mathrm{L}^{-1}$ (mean- $82 \mathrm{mg} \mathrm{L}^{-1}$ ), contributing $44 \%$ of the total cationic concentration overall. Ramkanali $\left(131 \mathrm{mg} \mathrm{L}^{-1}\right)$, Victoria $\left(130 \mathrm{mg} \mathrm{L}^{-1}\right)$, Bera (121 mg $\mathrm{L}^{-1}$ ) and Kuya (128 $\mathrm{mg} \mathrm{L}^{-1}$ ) showed relatively higher concentrations of calcium in comparison to the other sampling locations. This could be the result of weathering and dissolution of underlying rocks comprising of limestone $\left(\mathrm{CaCO}_{3}\right)$ and other calc-silicate minerals such as biotite, pyroxene, olivine, etc.

(Tiwari et al. 2016). Magnesium concentration in the analysed minewater samples fluctuated between 16 and $116 \mathrm{mg} \mathrm{L}^{-1}$ (mean- $58 \mathrm{mg} \mathrm{L}^{-1}$ ), accounting for $32 \%$ of total cations $\left(\mathrm{TZ}^{+}\right)$overall, in equivalent units. West Mudidih (112 $\left.\mathrm{mg} \mathrm{L}^{-1}\right)$ and Jamunia $\left(116 \mathrm{mg} \mathrm{L}^{-1}\right)$ showed the highest magnesium concentration among the sampled locations. The weathering of ferromagnesian minerals such as hornblende, olivine, etc. associated with metamorphic and igneous rocks and dolomite in sedimentary rocks form the primary magnesium source in the coal minewater of JCF. Sodium concentrations ranged between $9.7 \mathrm{mg} \mathrm{L}^{-1}$ and $133 \mathrm{mg} \mathrm{L}^{-1}$ (mean- $34.5 \mathrm{mg} \mathrm{L}^{-1}$ ), accounting for $21 \%$ of total cations overall, in equivalent units. Among the cations, potassium was the least dominant in the coal minewater of the study area, accounting for less than $3 \%$ of the total cations.

The physico-chemical characteristics of minewater of the study area for the hydrological year 20192020 are summarized by box plots (Fig. 2) which were plotted using Origin Pro 9.0 software.

The hydrochemical classification of the study area was done by plotting a Piper diagram (Fig. 3) using AqQA 1.1.1 software. The results revealed two main water types, $\mathrm{Ca}-\mathrm{Mg}-\mathrm{Cl}-\mathrm{SO}_{4}$ (red circle) and $\mathrm{Ca}-\mathrm{Mg}$ $\mathrm{HCO}_{3}$ (purple circle), which represent $60 \%$ and $33.33 \%$ of the coal minewater samples of the study site, respectively. The plotted points in the Piper diagram revealed $93.33 \%$ of the coal minewater samples of the study area fell in regions 1 and 2 which indicated the alkaline earth metals ( $\mathrm{Mg}$ and $\mathrm{Ca}$ ) to be dominant over the alkali metals ( $\mathrm{K}$ and $\mathrm{Na}$ ). The other water type observed was $\mathrm{NaCl}-\mathrm{SO}_{4}$ (orange circle) group, representing the remaining $(6.66 \%)$ minewater samples of the study site. The predominance of Ca-Mg-Cl-SO ${ }_{4}$ and $\mathrm{CaMg}^{-} \mathrm{HCO}_{3}$ agrees with earlier investigations in similar geological environment (Saini et al. 2016; Singh et al. 2016).

\subsubsection{Characteristics of trace and heavy metals}

Considering the most important trace/heavy metals from previous investigations in JCF, whose concentration levels affect human lives, nine trace/ heavy metals were chosen for this study. Their order of relative abundance was found to be $\mathrm{Fe}>\mathrm{Mn}>\mathrm{Zn}>\mathrm{Ni}>\mathrm{Pb}>\mathrm{Cu}>\mathrm{Cr}>\mathrm{As}>\mathrm{Cd}$. The trace/heavy metal concentrations in most of the analysed samples, barring a few exceptions, were lower than the permissible limits set by BIS 2012. Fe, Mn, Pb, Cu and Ni were observed to occur in concentrations exceeding the acceptable limits at some sites. Fe concentration ranged from 226 to $626 \mu \mathrm{g} \mathrm{L}^{-1}$ (mean- 
$421 \mathrm{~g} \mathrm{~L}^{-1}$ ) across the study sites. $74 \%$ of the samples had Fe concentration exceeding the maximum acceptable limit of $\mathrm{Fe}\left(300 \mu \mathrm{g} \mathrm{L}^{-1}\right)$. The $\mathrm{Mn}$ concentration ranged from $4.5 \mu \mathrm{g} \mathrm{L}^{-1}$ to $697.4 \mu \mathrm{g} \mathrm{L}^{-1}$ (mean$\left.118.4 \mu \mathrm{g} \mathrm{L}^{-1}\right)$. $27 \%$ of the analysed samples had $\mathrm{Mn}$ concentration exceeding the permissible limit of 300 $\mu \mathrm{g} \mathrm{L}^{-1}$, with Bera $\left(697.4 \mu \mathrm{g} \mathrm{L}^{-1}\right)$ and Kuya $\left(594 \mu \mathrm{g} \mathrm{L}^{-1}\right)$ having the highest Mn concentration. The concentrations of $\mathrm{Pb}$ varied between $7.6 \mu \mathrm{g} \mathrm{L}^{-1}$ and $24.8 \mu \mathrm{g} \mathrm{L}^{-1}$ (mean- $12.3 \mu \mathrm{g} \mathrm{L}^{-1}$ ), with $60 \%$ of the analysed samples crossing the maximum acceptable limit of $10 \mu \mathrm{g} \mathrm{L}^{-1}$. $\mathrm{Cr}$, Cd and As, which are highly toxic trace/ heavy metals were within the permissible limits set by BIS 2012. Ni concentration exceeded the maximum acceptable limit of $20 \mu \mathrm{g} \mathrm{L}^{-1}$ in $27 \%$ of the analysed minewater samples.

\subsection{Principal Component Analysis}

PCA was used in differentiating and verifying the potential sources of major contaminants in the study region. The distribution of variables of PCA among the minewater quality parameters in the factorial spread F1-F2 revealed three main groups (Fig. 4A). The $\mathrm{pH}$, total alkalinity, and bicarbonates $\left(\mathrm{HCO}_{3}{ }^{-}\right)$ comprised the first group (encircled in green), representing a strong correlation among the three parameters: $\mathrm{pH}$ and total alkalinity (0.654), $\mathrm{pH}$ and $\mathrm{HCO}_{3}{ }^{-}$(0.659), total alkalinity and $\mathrm{HCO}_{3}{ }^{-}(0.999)$. This group indicated that changes in $\mathrm{pH}$ was a result of the variations in concentration of total alkalinity of the minewater samples which correspond to bicarbonate concentration, predominant in the region. The second group (encircled in blue) consisted of $\mathrm{K}^{+}, \mathrm{Na}^{+}$and $\mathrm{Cl}^{-}$. The leaching of inorganic fertilizers which is composed of potassium chloride $(\mathrm{KCl})$ from nearby croplands serves as evidence for the association of chlorides $\left(\mathrm{Cl}^{-}\right)$with potassium $\left(\mathrm{K}^{+}\right)$. Chlorides and sodium are leached from rock formations in the region, along with industrial effluents and sewage contributing to its concentration levels. The third group (encircled in purple) was composed of EC, TDS, $\mathrm{TH}, \mathrm{Ca}^{2+}, \mathrm{Mg}^{2+}$ and $\mathrm{SO}_{4}{ }^{2-}$. The strong correlation between $\mathrm{Ca}^{2+}$ and $\mathrm{SO}_{4}{ }^{2-}$ ions could provide evidence on gypsum's role in mineralisation of the minewater, which is consistent with the geology of the region- consisting of limestone interbedded with layers of dolomite (Tiwari et al. 2016). The contribution of magnesium ion to the TDS and total hardness in the minewater samples indicates residence time of the underground minewater in the underlying carbonate aquifers due to its slow dissolution kinetics (Martins-Campina et al. 2008).

PCA of the trace/ heavy metal concentrations revealed three main groups (Fig. 4B). The first group (encircled in green) comprising of $\mathrm{Fe}$ and $\mathrm{Ni}$, showed a strong correlation (0.766) which is attributable to the geological formations of the region, indicating a lithogenic source. High Fe concentration could also be due to organic material present in the minewater, leaching from underlying soil/ rocks or seasonal variations affecting dissolved oxygen content (e.g. recharge) and in turn, Fe concentrations (Fashola et al. 2016). Zn, Cd, Cu and As formed the second group (encircled in blue). Zn, which is used as a minor additive in gasoline as well as automobile lubricants, is released into the environment during combustion or spillage. Coal combustion caused by mine fires deposit ash rich in these trace/ heavy metals on the soil surface which subsequently leach into the groundwater (Masto et al. 2011; Zheng et al. 2013). Occurrence of mine fires in Jharia Coalfield, where the sampling sites are situated, corroborates the trace/ heavy metals of the second group belonging to the same source, most likely coal mining wastes which is 
of anthropogenic origin (Siddiqui et al. 2020). The third group (encircled in purple) comprised of $\mathrm{Pb}$ and $\mathrm{Cr}$. The incineration of industrial wastes and coal, with its use in fuel tanks, bearings, solder, seals, and wheel weights contribute to $\mathrm{Pb}$ accumulation in the region. The brake linings of vehicles containing asbestos wear down with usage, which along with the usage of catalytic converters represent the source of $\mathrm{Cr}$ to be of vehicular origin (Mahato et al. 2017). Mn showed no conspicuous correlation with other trace/heavy metals which could be due to anthropogenic activities.

\subsection{Hierarchical Cluster Analysis}

The 15 locations from where samples were collected were grouped into clusters based on their physicochemical characteristics using HCA and expressed by a dendrogram (Fig. 5) plotted using XLSTAT 2019.1 software. The results revealed grouping of the sampling sites into two main clusters viz. Cluster 1 and Cluster 2. Two sub-clusters- $1 \mathrm{~A}$ and $1 \mathrm{~B}$ constituted Cluster 1 . Sub-cluster $1 \mathrm{~A}$ comprised of 3 sampling locations viz. Jamunia, Mudidih and West Mudidih which showed similar water quality characteristics with relatively higher concentrations of $\mathrm{Mg}^{2+}, \mathrm{SO}_{4}{ }^{2-}, \mathrm{Fe}, \mathrm{Pb}$ and total hardness. Subcluster 1B included 5 sampling locations viz. Khas Kusunda, Bera, Kuya, Ramkanali and Victoria. These locations were characterized by higher $\mathrm{Fe}$ and $\mathrm{SO}_{4}{ }^{2-}$ concentrations compared to the other clusters in addition to high levels of $\mathrm{Ca}^{2+}, \mathrm{Mn}$ and total hardness. Higher $\mathrm{Ca}^{2+}$ and $\mathrm{SO}_{4}{ }^{2-}$ ion concentration suggested that the presence of gypsum in the underlying rocks significantly affected the hydrogeological conditions of the locations under sub-cluster $1 \mathrm{~B}$. While $\mathrm{Ca}^{2+}$ and $\mathrm{SO}_{4}{ }^{2-}$ contributed significantly to the minewater hardness of the locations under sub-cluster $1 \mathrm{~A}, \mathrm{Mg}^{2+}$ and $\mathrm{SO}_{4}{ }^{2-}$ concentrations influenced the minewater hardness of locations under sub-cluster 1B. Cluster 1 represented natural mineralization of the coal minewater and was characterised by higher concentrations of $\mathrm{SO}_{4}{ }^{2-}, \mathrm{Ca}^{2+}$ and $\mathrm{Mg}^{2+}$ which contribute to its hardness, in addition to higher concentrations of Fe and Mn. Cluster 2 comprised of the sub-clusters-2A and 2B. 3 sampling locations viz. Bastacolla, Kharkharee and Sinidih constituted subcluster $2 \mathrm{~A}$. The minewater in these locations are characterised by high concentrations of total alkalinity. Sub-cluster 2B comprised of 4 sampling locations viz. Shatabdi, South Tisra, Muraidih and P.B. Area. This sub-cluster was characterised by high concentrations of total alkalinity, $\mathrm{HCO}_{3}{ }^{-}, \mathrm{NO}_{3}{ }^{-}, \mathrm{F}^{-}$along with $\mathrm{Pb}$. The increased $\mathrm{NO}_{3}{ }^{-}, \mathrm{Pb}$ and $\mathrm{Ni}$ levels in this group (Cluster 2) indicate the influence of anthropogenic activities in contaminating the hydrogeochemical conditions of the region.

\subsection{Assessment of potability of minewater}

Minewater quality of the study site for the year 2019-2020 was assessed by applying IWQI and HPI (Fig. 6) to the analyses from the aspect of major ion and trace/heavy metal concentration, respectively.

The quality of the analysed minewater samples from their respective sampling locations were classified as- excellent $(<1)$, good (1-2), poor (2-3), very poor (3-5) and unsuitable ( $>5)$; and low $(<15)$, medium $(15-30)$ and high (>30) based on the mean values of IWQI and HPI, respectively for the entire year (Table 4). 
Table 4

Minewater quality classification of the study area for the year 2019-2020

\begin{tabular}{|c|c|c|c|}
\hline $\begin{array}{l}\text { Sampling } \\
\text { location }\end{array}$ & $\begin{array}{l}\text { Mean IWQI } \\
\text { value }\end{array}$ & $\begin{array}{l}\text { Mean HPI } \\
\text { value }\end{array}$ & Category of minewater quality \\
\hline Mudidih & 3.08 & 25.35 & $\begin{array}{l}\text { Very poor, medium trace/heavy metal } \\
\text { contamination }\end{array}$ \\
\hline West Mudidih & 2.63 & 53.05 & Poor, high trace/heavy metal contamination \\
\hline Ramkanali & 3.02 & 33.25 & $\begin{array}{l}\text { Very poor, high trace/heavy metal } \\
\text { contamination }\end{array}$ \\
\hline Kharkharee & 2.85 & 40.50 & Poor, high trace/heavy metal contamination \\
\hline Sinidih & 2.48 & 44.75 & Poor, high trace/heavy metal contamination \\
\hline Muraidih & 5.08 & 24.80 & $\begin{array}{l}\text { Unsuitable, medium trace/heavy metal } \\
\text { contamination }\end{array}$ \\
\hline Shatabdi & 1.97 & 25.30 & $\begin{array}{l}\text { Good, medium trace/heavy metal } \\
\text { contamination }\end{array}$ \\
\hline Bastacolla & 2.48 & 33.75 & Poor, high heavy metal contamination \\
\hline Victoria & 3.26 & 31.55 & $\begin{array}{l}\text { Very poor, high trace/heavy metal } \\
\text { contamination }\end{array}$ \\
\hline Bera & 3.94 & 25.85 & $\begin{array}{l}\text { Very poor, medium trace/heavy metal } \\
\text { contamination }\end{array}$ \\
\hline Kuya & 3.29 & 23.70 & $\begin{array}{l}\text { Very poor, medium trace/heavy metal } \\
\text { contamination }\end{array}$ \\
\hline South Tisra & 2.25 & 42.05 & Poor, high trace/heavy metal contamination \\
\hline Khas Kusunda & 2.47 & 27.80 & $\begin{array}{l}\text { Poor, medium trace/heavy metal } \\
\text { contamination }\end{array}$ \\
\hline PB Area & 3.24 & 18.40 & $\begin{array}{l}\text { Very poor, medium trace/heavy metal } \\
\text { contamination }\end{array}$ \\
\hline Jamunia & 1.97 & 50.30 & Good, high trace/heavy metal contamination \\
\hline
\end{tabular}

\subsection{Adequacy of using an integrated water quality index and heavy metal pollution index}

The integrated approach of combining both IWQI and HPI for qualitative studies of minewater could prove to be efficient in characterization and classification of water for its utilization in various purposes. This method helps in making decisions about the destination of pumped-out minewater discharges and its subsequent treatment (if any) to improve the quality of the water. In this study, Jamunia showed high trace/heavy metal contamination (HPI- 50.30) especially of Fe $\left(553 \mu \mathrm{g} \mathrm{L}^{-1}\right)$ and Ni $\left(31 \mathrm{~g} \mathrm{~L} \mathrm{~L}^{-1}\right)$, while the rest of the water quality parameters (all physiological parameters including all the major ions) were 
within the permissible limits of drinking water standards. From this, it is apparent that installing a water softening unit or iron filters to treat the pumped-out minewater discharges to utilize it for potable purposes is warranted. Based on the results obtained by application of IWQI and HPI, respectively to the minewater analyses, it was revealed that barring the minewater of Shatabdi $(1.98 ; 25.31)$, all the other locations discharged minewater that were unsuitable for direct consumption and require prior treatment. West Mudidh $(2.63 ; 53.03)$, Kharkharee $(2.85 ; 40.49)$, Sinidih $(2.48 ; 44.76)$, Bastacolla $(2.20 ; 33.75)$, South Tisra $(2.14 ; 42.03)$ yielded minewater of poor quality with high trace/heavy metal concentration. Khas Kusunda $(2.46 ; 27.81)$ yielded minewater of poor quality with medium trace/heavy metal concentration while minewater quality of Mudidih $(3.08 ; 25.34)$, Bera $(3.94 ; 25.85)$, Kuya $(3.29 ; 23.71)$ and P.B. Area $(3.24 ; 18.38)$ were deemed to be very poor with medium trace/heavy metal concentration. Ramkanali $(3.02 ; 33.25)$ and Victoria $(3.26 ; 31.53)$ were classified as very poor with high trace/heavy metal concentration. Muraidih $(5.08 ; 24.78)$ was found to have a high IWQI value and thus deemed unsuitable for direct consumption. Although the pumped-out coal minewater of Jamunia had a IWQI value of 1.97, it requires treatment prior to consumption due to high trace/heavy metal concentration (HPI- 50.30). The mean HPI values of trace/heavy metal concentrations were found to be 35.62 for the pre-monsoon month of March-April and 31.09 for the post-monsoon month of October-November, which fall below the critical pollution index limit of 100 . Minewater quality during post-monsoon was found to be better in terms of trace/heavy metal concentration.

\subsection{Geospatial variation of minewater based on IWQI and $\mathrm{HPI}$}

The application of IWQI and HPI to the minewater analyses summarized the minewater quality in the study area. The analysed samples from the 15 locations were interpolated using IDW technique in ArcGIS 10.2.2 to represent the spatial variation in minewater quality over the sampled sites (Fig. 7, 8). The interpolation of IWQI and HPI values of analysed minewater could potentially enable efficient water resource management by assessing the water quality of JCF. The geospatial variation of minewater pumped out from the underground coal mines of JCF quality using IWQI (Fig. 7) and HPI (Fig. 8) showed only Shatabdi to have minewater of potable quality with an IWQI of 1.98 and HPI of 25.31, whereas Jamunia, despite having a low IWQI (1.97) had a high trace/heavy metal concentration (HPI- 50.30), rendering it unsuitable for direct consumption.

\section{Conclusion}

The maintenance of ionic balance in potable water is important, as a deficiency or an excess in ionic concentration could have an adverse impact on human health. Thus, in lieu of the traditional WQI, an IWQI was used which considers both the threshold limits (viz. maximum acceptable limit and permissible limit) in its calculation. Limitations of previous WQI such as eclipsing, aggregation and ambiguity are overcome by this model. IWQI is flexible in its usage as the percent deficit can be adjusted as per the nature of the environment. While IWQI evaluates the ionic concentration in the minewater, HPI focusses on trace/heavy metal contamination in the minewater. Fe and $\mathrm{Mn}$ were revealed to be the main

Page 15/26 
contaminants of the pumped-out underground minewater along with $\mathrm{Cu}, \mathrm{Pb}, \mathrm{Ni}$. The integrated approach of using IWQI and HPI can adequately help in making decisions about the destination of the pumped-out coal minewater or the type of treatment to be employed to improve the quality of the minewater. PCA revealed the trace/ heavy metal concentration to be from a mixed source of anthropogenic and lithogenic origin. The multivariate statistical approach holistically identified areas of contamination within the study area giving an assessment of the quality of minewater and its suitability for potable purposes and laying the framework for future investigations in augmenting minewater for potable purposes.

\section{Declarations}

Ethics approval and consent to participate

Not applicable.

Consent for publication

Not applicable.

Availability of data and materials

The data that support the findings of this study are available from the corresponding author upon request.

\section{Competing interests}

We wish to confirm that there are no known conflicts of interest associated with this publication and there has been no significant financial support for this work that could have influenced its outcome.

\section{Funding}

No funding was received by the authors.

Authors' contributions

Gurdeep Singh supervised the work. Pritam Mazinder Baruah performed the analysis and calculations and wrote the manuscript in consultation with Gurdeep Singh.

Acknowledgements

The authors are grateful to Indian Institute Technology (Indian School of Mines) Dhanbad for providing all the necessary laboratory facilities during the research work.

\section{References}


1. Association (APHA), A.P.H. (2017). Standard methods for examination of water and wastewater, 23rd ed. APHA, AWWA, WPCF, Washington.

2. Bhardwaj, R., Gupta, A., Garg, J.K. (2017). Evaluation of heavy metal contamination using environmetrics and indexing approach for River Yamuna, Delhi stretch, India. Water science 31, 5266.

3. Bureau of Indian Standards (BIS), BIS: 10500, 2012. Guidelines for drinking water quality standards.

4. Chandrasekaran, A., Ravisankar, R., Harikrishnan, N., Satapathy, K.K., Prasad, M.V.R., Kanagasabapathy, K.V. (2015). Multivariate statistical analysis of heavy metal concentration in soils of Yelagiri Hills, Tamilnadu, India-Spectroscopical approach. Spectrochimica Acta Part A: Molecular and Biomolecular Spectroscopy 137, 589-600.

5. Fashola, M.O., Ngole-Jeme, V.M., Babalola, O.O., 2016. Heavy metal pollution from gold mines: environmental effects and bacterial strategies for resistance. International journal of environmental research and public health 13, 1047.

6. Giri, S., Singh, A.K. (2014). Assessment of surface water quality using heavy metal pollution index in Subarnarekha River, India. Water Quality, Exposure and Health 5, 173-182.

7. Hossain, M., Patra, P. K. (2020). Hydrogeochemical characterisation and health hazards of fluoride enriched groundwater in diverse aquifer types. Environmental Pollution, 258, 113646.

8. Kamtchueng, B.T., Fantong, W.Y., Wirmvem, M.J., Tiodjio, R.E., Takounjou, A.F., Ngoupayou, J.R.N., Kusakabe, M., Zhang, J., Ohba, T., Tanyileke, G. (2016). Hydrogeochemistry and quality of surface water and groundwater in the vicinity of Lake Monoun, West Cameroon: approach from multivariate statistical analysis and stable isotopic characterization. Environmental monitoring and assessment 188, 524.

9. Kozisek, F. (2005). Health risks from drinking demineralised water. Nutrients in Drinking Water 1 , 148-163.

10. Madzivire, G., Gitari, W.M., Vadapalli, V.K., Ojumu, T.V., Petrik, L.F. (2011). Fate of sulphate removed during the treatment of circumneutral mine water and acid mine drainage with coal fly ash: Modelling and experimental approach. Minerals Engineering 24, 1467-1477.

11. Mahato, M.K., Singh, G., Singh, P.K., Singh, A.K., Tiwari, A.K. (2017). Assessment of mine water quality using heavy metal pollution index in a coal mining area of Damodar River Basin, India. Bulletin of environmental contamination and toxicology 99, 54-61.

12. Martins-Campina, B., Huneau, F., Fabre, R. (2008). The Eaux-Bonnes landslide (Western Pyrenees, France): overview of possible triggering factors with emphasis on the role of groundwater. Environmental geology 55, 397-404.

13. Masto, R.E., Ram, L.C., George, J., Selvi, V.A., Sinha, A.K., Verma, S.K., Rout, T.K., Priyadarshini, Prabal, P. (2011). Status of some soil trace elements and their potential human health risks around a coal beneficiation plant. International journal of coal preparation and utilization 31, 61-77.

14. Milovanovic, M. (2007). Water quality assessment and determination of pollution sources along the Axios/Vardar River, Southeastern Europe. Desalination 213, 159-173. 
15. Mohan, S.V., Nithila, P., Reddy, S.J. (1996). Estimation of heavy metals in drinking water and development of heavy metal pollution index. Journal of Environmental Science \& Health Part A 31, 283-289.

16. Mukate, S., Wagh, V., Panaskar, D., Jacobs, J.A., Sawant, A. (2019). Development of new integrated water quality index (IWQI) model to evaluate the drinking suitability of water. Ecological indicators $101,348-354$.

17. Ogwueleka, T.C. (2015). Use of multivariate statistical techniques for the evaluation of temporal and spatial variations in water quality of the Kaduna River, Nigeria. Environmental monitoring and assessment 187, 137.

18. Panigrahy, B.P., Singh, P.K., Tiwari, A.K., Kumar, B., Kumar, A. (2015). Assessment of heavy metal pollution index for groundwater around Jharia coalfield region, India. Journal of Biodiversity and Environmental Sciences 6, 33-39.

19. Ponsadailakshmi, S., Sankari, S.G., Prasanna, S.M., Madhurambal, G. (2018). Evaluation of water quality suitability for drinking using drinking water quality index in Nagapattinam district, Tamil Nadu in Southern India. Groundwater for Sustainable Development 6, 43-49.

20. Rakotondrabe, F., Ngoupayou, J.R.N., Mfonka, Z., Rasolomanana, E.H., Abolo, A.J.N., Ako, A.A., 2018. Water quality assessment in the Bétaré-Oya gold mining area (East-Cameroon): multivariate statistical analysis approach. Science of the total environment 610, 831-844.

21. Rylander, R. (2008). Drinking water constituents and disease. The Journal of nutrition 138, 423S425S.

22. Saini, V., Gupta, R.P., Arora, M.K. (2016). Environmental impact studies in coalfields in India: a case study from Jharia coal-field. Renewable and Sustainable Energy Reviews 53, 1222-1239.

23. Sarkar, B.C., Mahanta, B.N., Saikia, K., Paul, P.R., Singh, G. (2007). Geo-environmental quality assessment in Jharia coalfield, India, using multivariate statistics and geographic information system. Environmental geology 51, 1177.

24. Shu, W. (2015). Pay attention to the human health risk of drinking low mineral water.

25. Siddiqui, A.U., Jain, M.K., Masto, R.E. (2020). Pollution evaluation, spatial distribution, and source apportionment of trace metals around coal mines soil: the case study of eastern India. Environmental Science and Pollution Research 1-13.

26. Singh, A.K., Mahato, M.K., Neogi, B., Tewary, B.K., Sinha, A. (2012). Environmental geochemistry and quality assessment of mine water of Jharia coalfield, India. Environmental Earth Sciences 65, 49-65.

27. Singh, A.K., Varma, N.P., Mondal, G.C. (2016). Hydrogeochemical investigation and quality assessment of mine water resources in the Korba coalfield, India. Arabian Journal of Geosciences 9 , 278.

28. Singh, G., Kamal, R.K. (2017). Heavy metal contamination and its indexing approach for groundwater of Goa mining region, India. Applied Water Science 7, 1479-1485.

29. Tiwari, A.K., De Maio, M., Singh, P.K., Mahato, M.K. (2015). Evaluation of surface water quality by using GIS and a heavy metal pollution index (HPI) model in a coal mining area, India. Bulletin of 
environmental contamination and toxicology 95, 304-310.

30. Tiwari, A.K., Singh, P.K., Mahato, M.K. (2016). Hydrogeochemical investigation and qualitative assessment of surface water resources in West Bokaro coalfield, India. Journal of the Geological Society of India 87, 85-96.

31. WHO, 2011. Guidelines for drinking-water quality. World Health Organization 216, 303-4.

32. Yadav, K., Raphi, M., Jagadevan, S. (2021). Geochemical appraisal of fluoride contaminated groundwater in the vicinity of a coal mining region: Spatial variability and health risk assessment. Geochemistry, 81(1), 125684.

33. Zheng, Y., Gao, Q., Wen, X., Yang, M., Chen, H., Wu, Z., Lin, X. (2013). Multivariate statistical analysis of heavy metals in foliage dust near pedestrian bridges in Guangzhou, South China in 2009. Environmental earth sciences 70, 107-113.

\section{Figures}

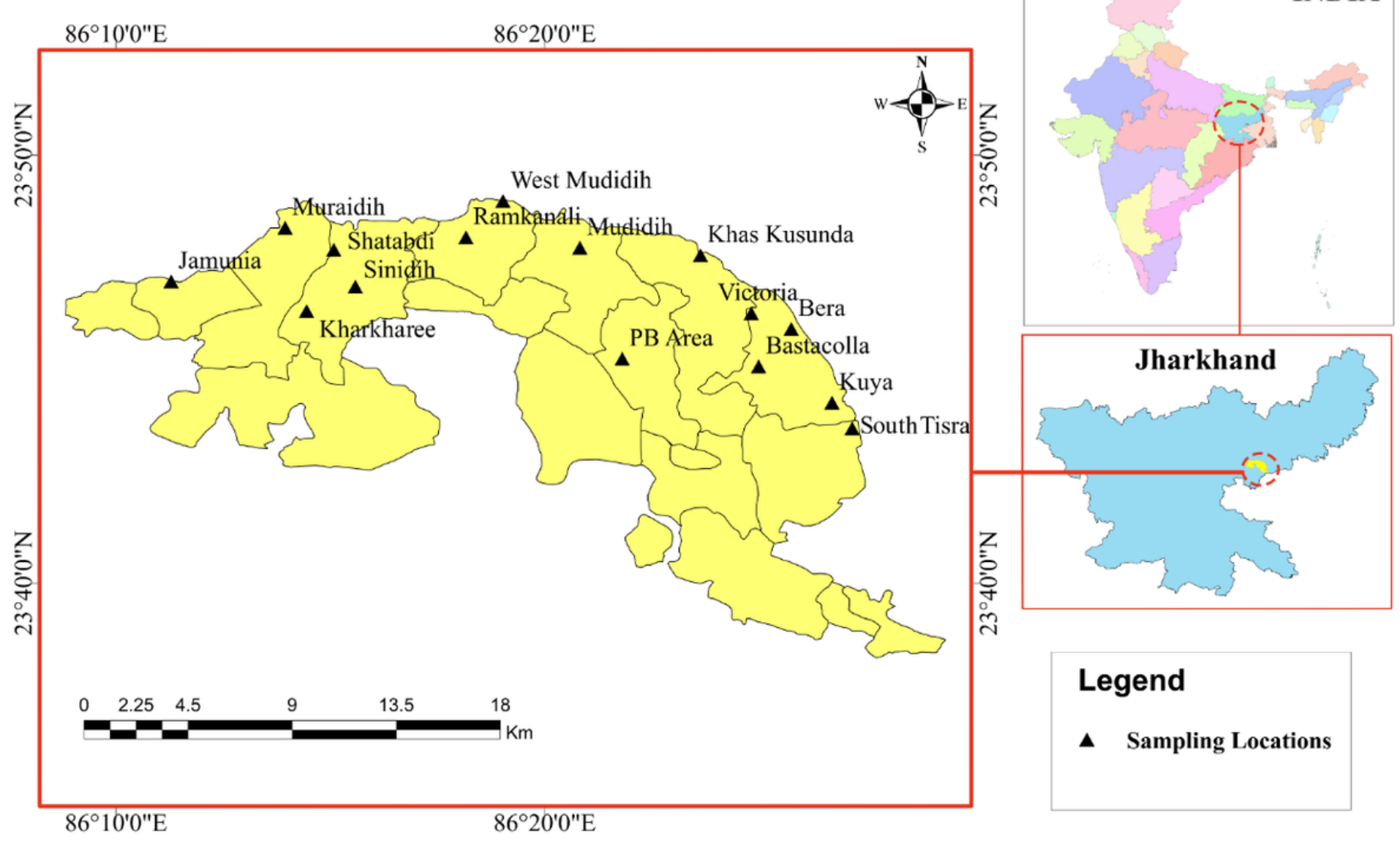

\section{Figure 1}

Sampling locations plotted on the study area map. 


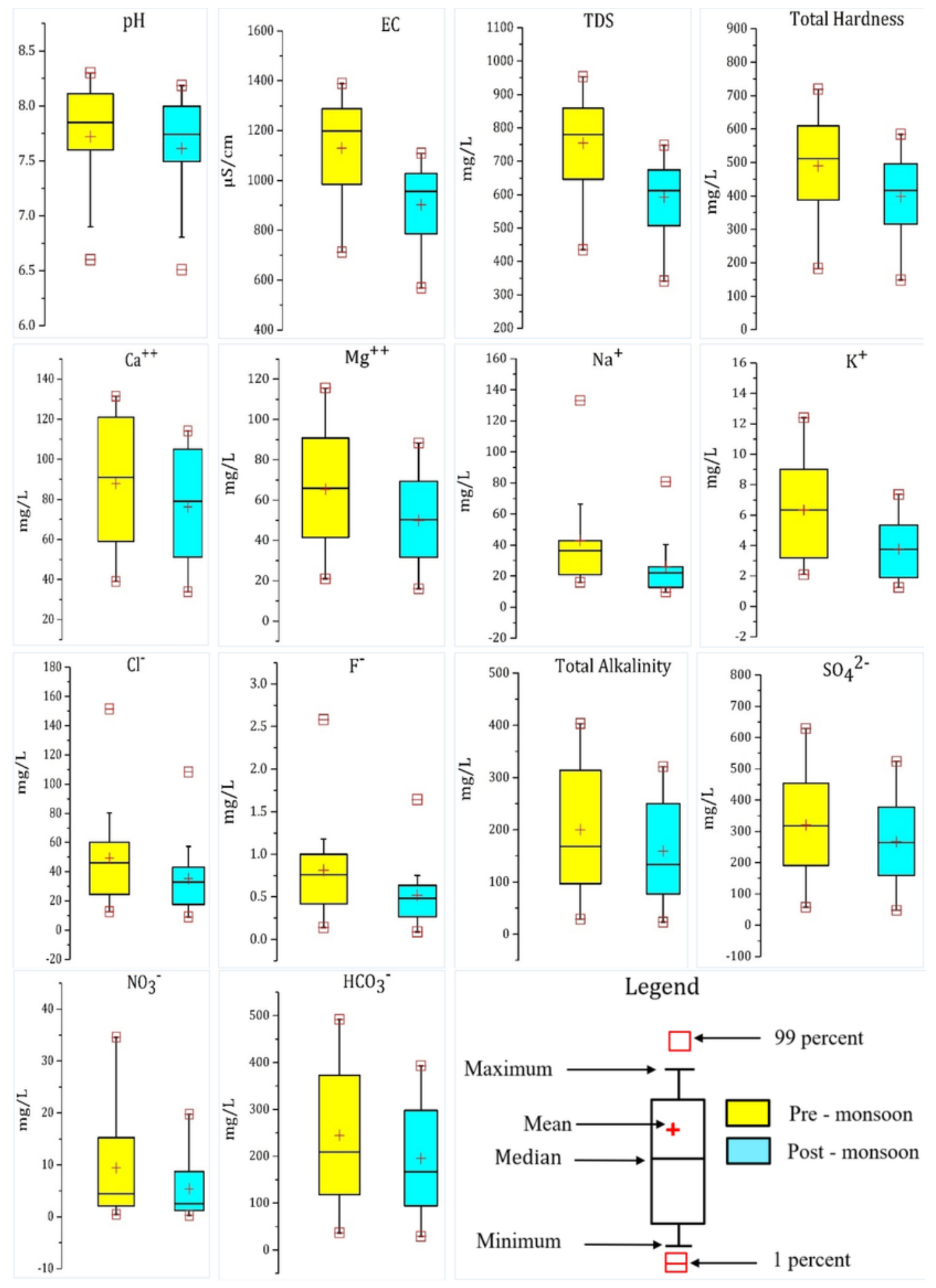

Figure 2

Box plot of physico-chemical parameters of coal minewater for the year 2019-2020. 


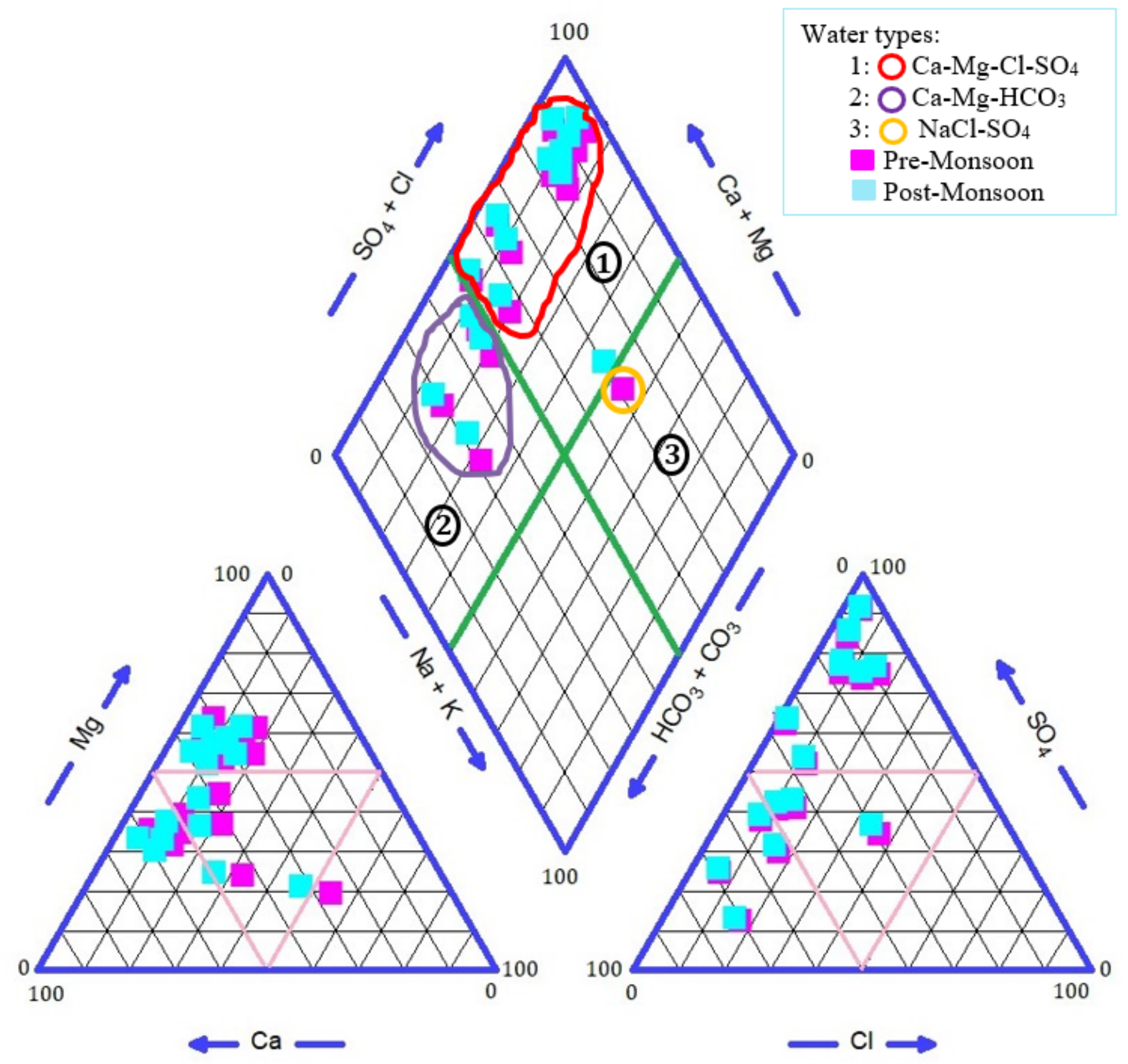

Figure 3

Piper diagram identifying the major water types in JCF for the year 2019-2020. 


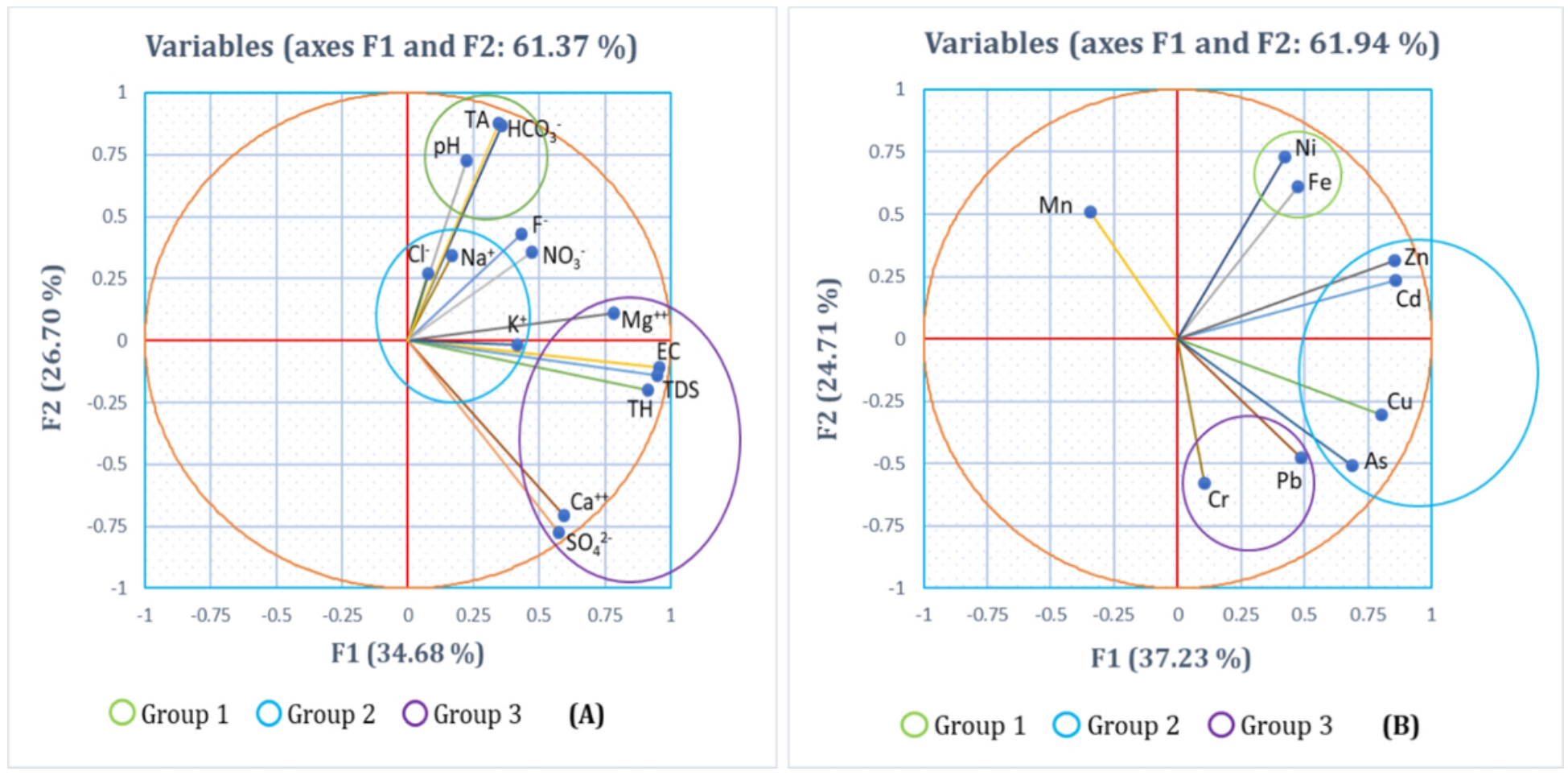

Figure 4

PCA of (A) the physico-chemical parameters with major ions; $(B)$ trace / heavy metals present in the coal minewater samples of JCF. 


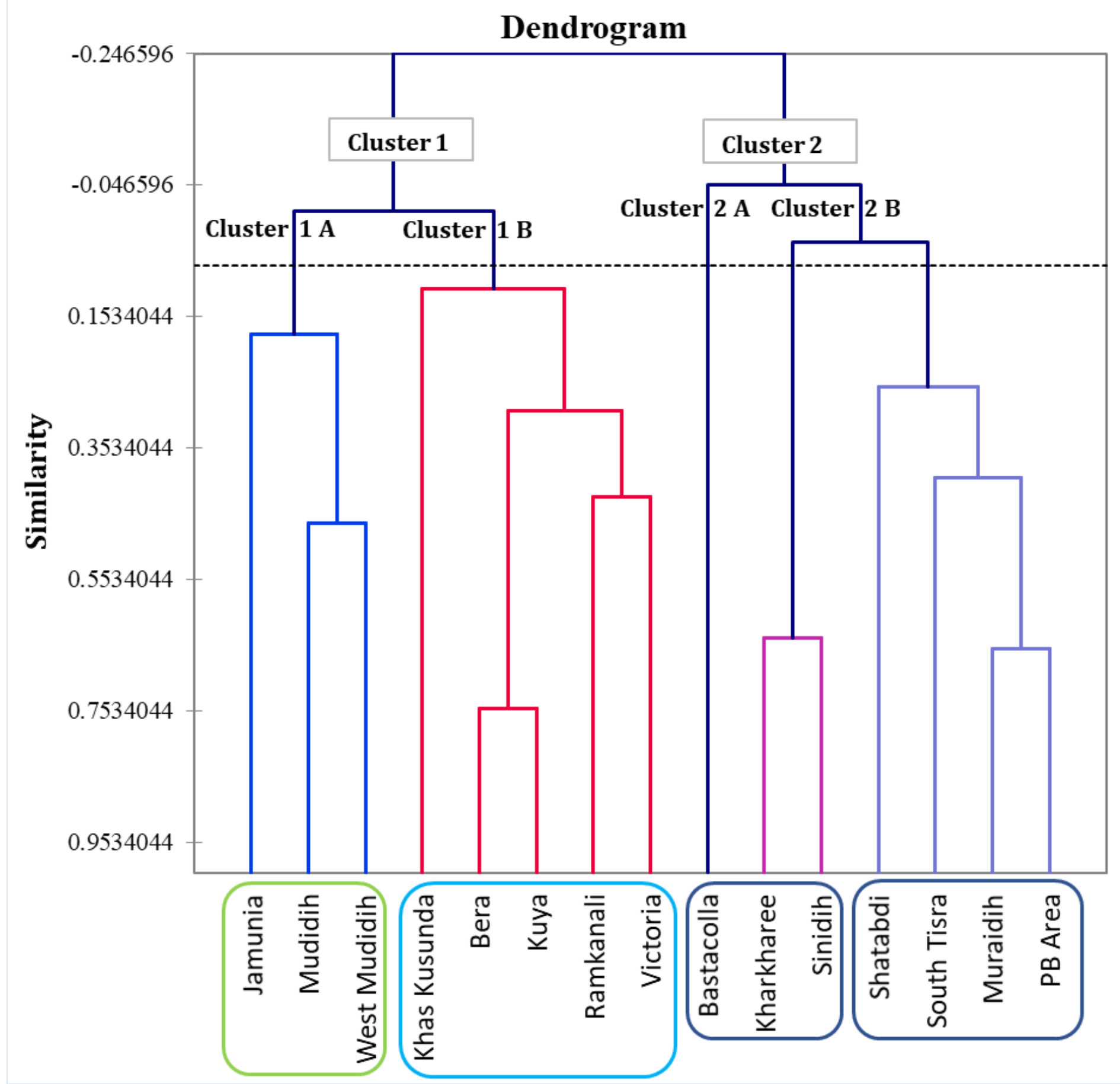

Figure 5

Dendrogram of HCA based on similarities among the sampling locations. 


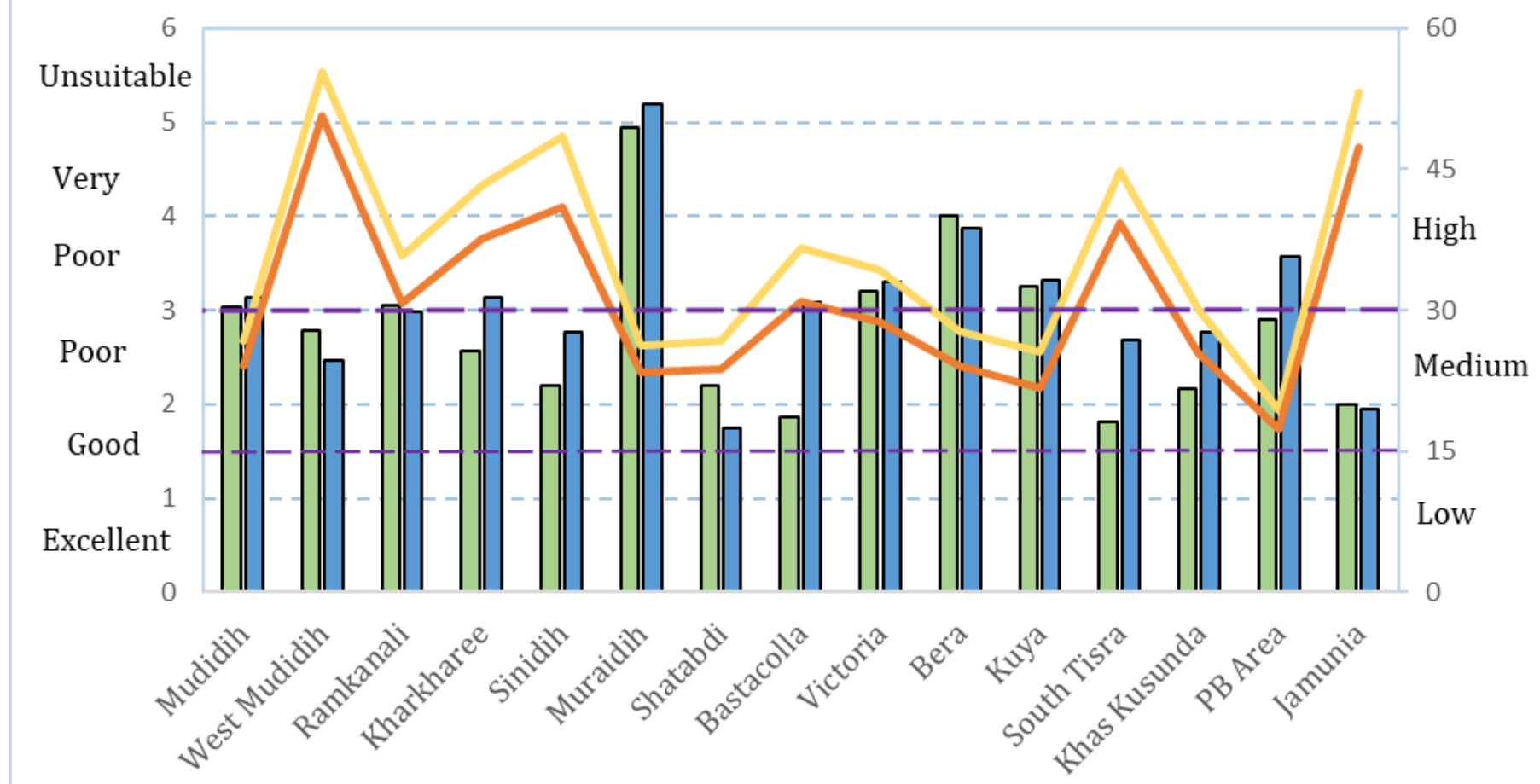

$\square$ IWQI Pre-Monsoon

$\square$ IWQI Post-Monsoon

HPI Pre-Monsoon

HPI Post-Monsoon

Figure 6

Graphical representation of IWQI and HPI of coal minewater of the study area 


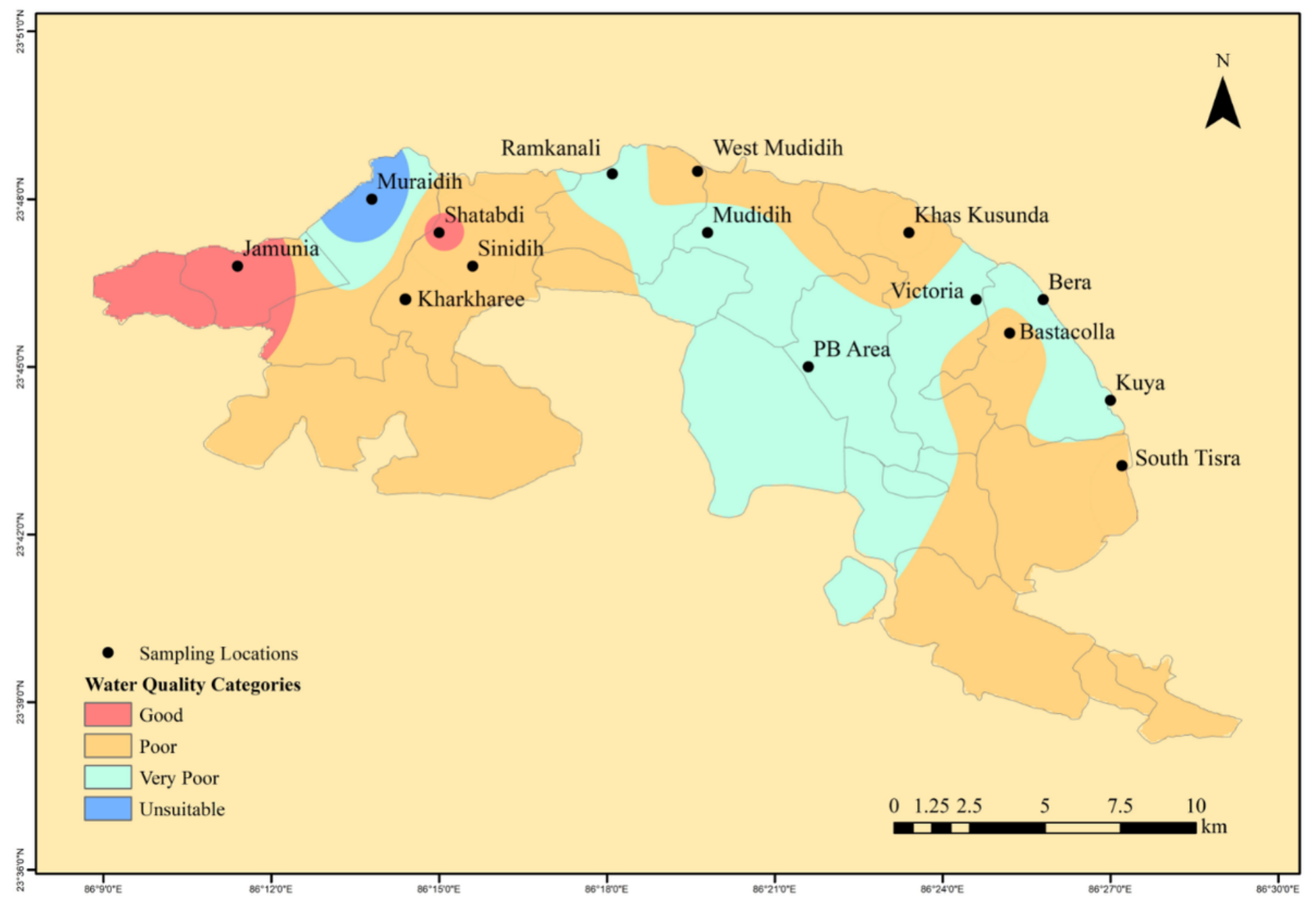

Figure 7

Spatial distribution of minewater quality based on IWQI values 


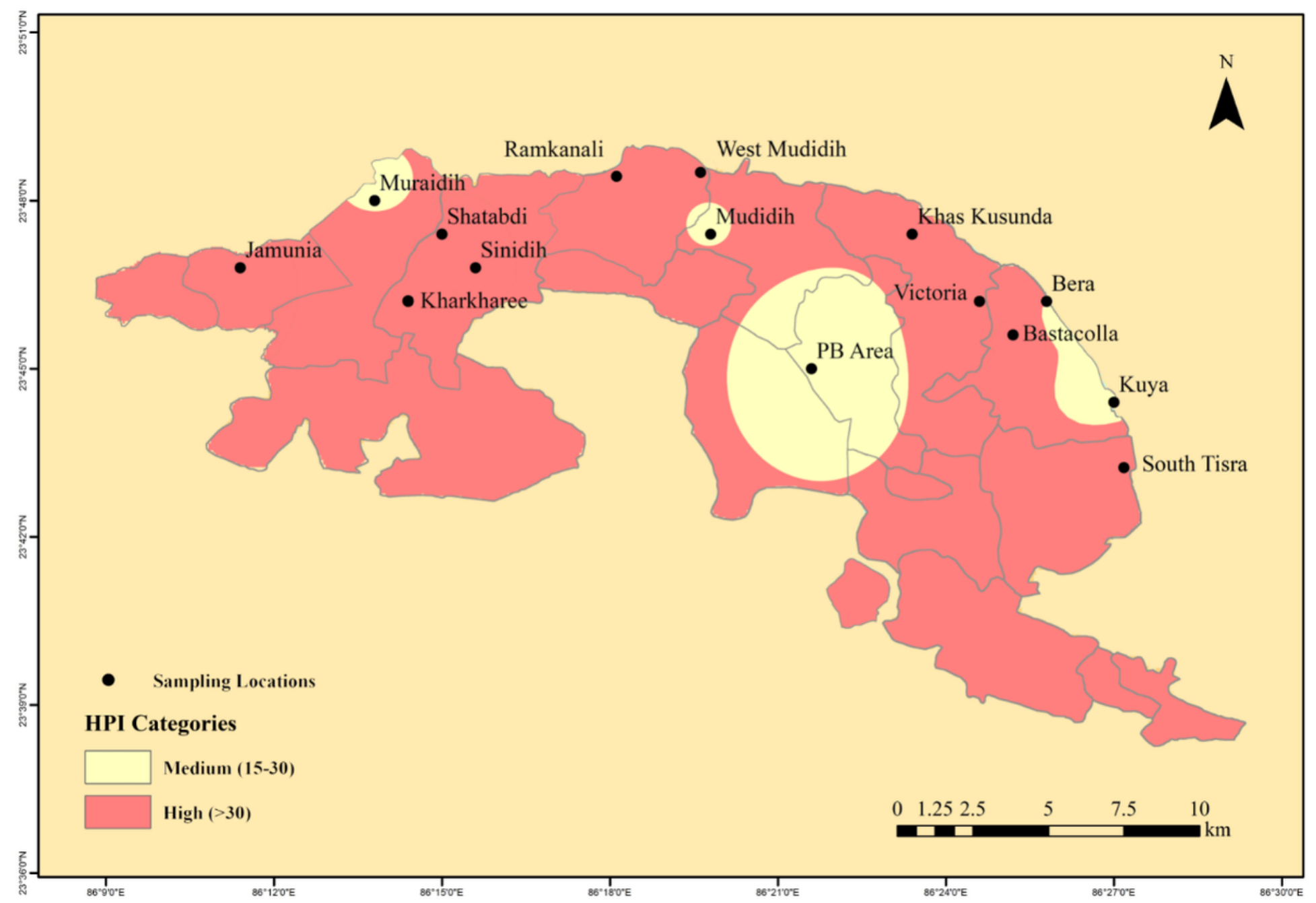

Figure 8

Spatial distribution of minewater quality based on HPI values 